\title{
Descriptions of digenean parasites from three snail species, Bithynia fuchsiana (Morelet), Parafossarulus striatulus Benson and Melanoides tuberculata Müller, in North Vietnam
}

\author{
V. V. BESPROZVANNYKH ${ }^{1}$, H. D. NGO ${ }^{2}$, N. V. HA ${ }^{2}$, N. M. HUNG ${ }^{2}$, K. V. ROZHKOVAN ${ }^{1}$, \\ A. V. ERMOLENKO
}

\begin{abstract}
${ }^{1}$ Department of Parasitology, Institute of Biology and Soil Sciences, Far East Branch of RAS, Vladivostok, Russia; ${ }^{2}$ Department of Parasitology, Institute of Ecology and Biological Resources, Vietnamese Academy of Science and Technology, Hanoi, Vietnam
\end{abstract}

\begin{abstract}
Summary
For first time, 3 species of prosobranchial snails (Bithynia fuchsiana, Parafossarulus striatulus (Bithyniidae) and Melanoides tuberculata (Thiaridae)) from North Vietnam were studied for presence of the parthenitae and cercariae of Trematoda. The morphology of 12 species of larvae belonging to 8 families (Cyathocotylidae, Pleurogenidae, Lecithodendriidae, Paramphistomidae, Heterophyidae, Notocotylidae, Psilostomidae and Echinostomatidae) was described. Data on the life cycles of 3 species (Echinochasmus japonicus, Notocotylus intestinalis and Sphaeridiotrema monorchis) as well as molecular data on $28 \mathrm{~S}$ rDNA were obtained. There was no intraspecific variability found in any of the sequences examined. The $28 \mathrm{~S}$ rDNA sequence length determined for $N$. intestinalis was $1315 \mathrm{bp}$, while that of $S$. monorchis was $1292 \mathrm{bp}$, and that of E. japonicus was $1288 \mathrm{bp}$.
\end{abstract}

Keywords: North Vietnam; prosobranchial snails; parthenitae and cercaria; life cycles; molecular data

\section{Introduction}

The first study of parasites in the territory of Vietnam was conducted at the end of the nineteenth century, when Bourger (1886) and Cattoin (1888) (cit.on: Railliet 1924) described two digenean species, Fasciola gigantica Cobbold, 1885 and Gastrothylax crumenifer (Creplin, 1847), from cattle. A total of 395 identified digenean species belonging to 51 families have now been found in humans, mammals, birds, reptiles and amphibians (Le, 2000; Le \& Ngo, 2007), in addition to the more than 170 digenean species known from fishes.

However, the publications addressing the role of mollusks and other animals as intermediate hosts of flukes are limited. At present, there is a clear lack of published data on the morphology of flukes in freshwater snails in Vietnam, with only a few papers published on this topic. Knowledge of the distribution and density of the first intermediate hosts of these parasites, species of freshwater snails, is important for determining the transmission patterns of trematodes (World Health Organization 2004). Four snail species, Lymnaea viridis Quoy et Gaimard, L. swinhoei Adams, Parafossarulus striatulus and Melanoides tuberculata, have been reported to be intermediate hosts for digeneans infecting poultry (Le et al., 1990). Lymnaea swinhoei have been reported to be infected with six digenean species (Le et al., 1995). Five types of cercariae and seven types of metacercariae have been found in $P$. striatulus (Le et al., 2000). In addition, snails of the family Viviparidae, which are often used for human consumption, may exhibit a high prevalence of metacercariae, e.g., $69.31 \%$ in Angulyagra polyzonata Frauenfeld, $40.06 \%$ in Cipangopaludina lecythoides (Benson) and 54.16 \% in Sinotaia aeruginosa (Reeve) (Le \& The, 1993).

In March 2011, three snail species, Bithynia fuchsiana (Morelet), Parafossarulus striatulus Benson (Bithyniidae Gray) and Melanoides tuberculata Muller (Thiaridae Gill), were collected in the Red River basin (North Vietnam) to perform research on digenean larvae. From these snails, we identified 12 types of digenean parasites belonging to eight families. Five of these types were used to infect the second intermediate (fish) and definitive hosts to study their life cycles. Adult worms were found in 3 species of experimental hosts: Echinochasmus japonicus Tanabe, 1926, Notocotylus intestinalis Tubangui, 1932 and Sphaeridiotrema monorchis Xiumin et Qingquan, 1983. N. intestinalis and E. japonicus were reported in the territory of Vietnam previously, while $S$. monorchis was found in Vietnam for the first time. The other types were defined to the genus or family level only, and their identification will be carried out in the future. 


\section{Materials and methods}

A total of 176 specimens of Bithynia fuchsiana (Morelet) and 430 specimens of Parafossarulus striatulus Benson (Bithyniidae) were collected from rice fields in Nam Dinh province $\left(20^{\circ} 09^{\prime} \mathrm{N}, 106^{\circ} 17^{\prime} \mathrm{E}\right)$ in addition to 100 specimens of Melanoides tuberculata Muller (Thiaridae) from the Red River near Hanoi $\left(21^{\circ} 02^{\prime} \mathrm{N}, 105^{\circ} 51^{\prime} \mathrm{E}\right)$. The snails were transported to a temporary laboratory in the area, where they were identified according to keys produced by Thanh (1980).

The snails were then examined for digenean infections using shedding methods. Snail samples were placed individually in small plastic containers with $5 \mathrm{ml}$ of tap water and left for $24 \mathrm{~h}$ for shedding. The description and identification of cercariae were performed both in cercariae that had been retrieved by shedding and in living specimens. All measurements were performed in cercariae fixed in hot $4 \%$ formol. Cercariae were identified according to the keys of Ginetsinskaya (1968).

The second intermediate hosts for Haplorchis sp., Microparyphium sp., Echinochasmus japonicus and Sphaeridiotrema monorchis are the fishes Rhodeus sericeus sericeus (Pallas), Phoxinus perenurus mantschuricus Berg and Pseudorasbora parva (Schlegel), respectively. Fishes were caught in natural reservoirs and examined to ensure that they were free of infection with larval Digenea. Reproduction of the snails was carried out under laboratory conditions. Experimental animals, including chickens Gallus gallus (L.), dom., ducks Anas platyrhynchos L., dom. and rats Rattus norvegicus (Berkenhout), were used as definitive hosts. All experimental procedures were conducted at $18-20^{\circ} \mathrm{C}$. Adult worms, obtained from definitive hosts, were washed in distilled water, killed in boiling distilled water, and preserved in $70 \%$ ethanol. Whole-mount preparations were produced by staining specimens with alum carmine, dehydrating the worms in a graded ethanol series and clearing in xylene, followed by mounting in Canada balsam under a coverslip on a glass slide. All measurements are given in micrometers $(\mu \mathrm{m})$.

Molecular experiments. Adult specimens of Notocotylus intestinalis, Sphaeridiotrema monorchis and Echinochasmus japonicus were obtained during experimental work and fixed in $96 \%$ ethanol for genetic analysis. DNA was extracted from whole worms using the Hot-SHOT technique (Truett, 2006).
Nuclear 28S rDNA was amplified via polymerase chain reaction (PCR) with the following primers: digL2 (5'-AAG CAT ATC ACT AAG CGG-3') and 1500R (5'-GCT ATC CTG AGG GAA ACT TCG-3') (Tkach et al., 2003). The initial PCR step was carried out in a total volume of $20 \mu \mathrm{l}$ containing $0.25 \mathrm{mM}$ of each primer pair, $1 \mu \mathrm{l}$ of DNA, $1 \times$ Taq buffer, $1.25 \mathrm{mM}$ dNTP, $2 \mathrm{mM}$ magnesium and 1 unit of Taq polymerase. Amplification of a 1500-bp fragment of the 28S rDNA gene was performed in a GeneAmp 9700 thermal cycler (Applied Biosystems, Foster City, CA, USA) using a program consisting of a 3-min denaturation hold at $94{ }^{\circ} \mathrm{C}$, followed by 40 cycles of $30 \mathrm{~s}$ at $94{ }^{\circ} \mathrm{C}, 30 \mathrm{~s}$ at $52{ }^{\circ} \mathrm{C}$ and $2 \mathrm{~min}$ at $72{ }^{\circ} \mathrm{C}$, and a final $7-$ min extension hold at $72{ }^{\circ} \mathrm{C}$. Negative and positive controls were performed using both primers. The obtained PCR products were directly sequenced using the ABI Big Dye Terminator v.3.1 Cycle Sequencing Kit, as recommended by the manufacturer, with the internal sequencing primers ECD2, 900F and 1200R (Tkach et al., 2003). The PCR products were analyzed using an ABI 3130 genetic analyzer at the Institute of Biology and Soil Science FEB RAS. The ribosomal DNA sequences were assembled and aligned using the MEGA 5.02 software alignment explorer with default options (Tamura et al., 2011).

\section{Results}

Family Cyathocotylidae Mühling, 1898

1. Holostephanus sp. 1 (Fig.1; Table 1)

First intermediate host: Bithynia fuchsiana (1 specimen; in this place and further - number of infected snails).

Habitat: rice fields, Nam Dinh province.

Sporocyst: Body thread-shaped with terminal birth pore.

Cercaria: Oval, with poorly expressed ventral body cavity, spined on ventral side from anterior end of body to posterior margin of anterior organ and on dorsal one from anterior end to level of last third of body. Pharynx, short prepharynx and esophagus present. Caeca terminate at level of anterior margin of excretory bladder. Cercaria has glands in the form of six pairs of cells placed to left and right of median line of body at level of anterior organ and 12 cells placed laterally along the body. Ducts of the first cells opened at anterior end of body, but those of the second cells opened at site of its disposition. Anlagen of reproductive organs found anterior to excretory bladder. Excretory system includes excretory bladder and row of

Table 1. Sizes $(\mu \mathrm{m})$ of cercariae Holostephanus Szidat, 1936

\begin{tabular}{|c|c|c|c|c|}
\hline Signs & Holostephanus sp. 1 & $\begin{array}{c}\text { H. cobitidis } \\
\text { (our data; unpublished) }\end{array}$ & Holostephanus sp. 2 & $\begin{array}{c}\text { H. nipponicus } \\
\text { (in Besprozvannykh, 2003) }\end{array}$ \\
\hline Body & $123-188 \times 50-69$ & $250-260 \times 130-150$ & $196-0.223 \times 65-100$ & $280-340 \times 90-110$ \\
\hline Oral organ & $27-39 \times 27-34$ & $39-56 \times 34-45$ & $31-39 \times 31-35$ & $38-44 \times 27-38$ \\
\hline Pharynx & $12-15 \times 12$ & $17-22$ in diameter & 12 in diameter & $11-14$ in diameter \\
\hline Tail & $266-289 \times 31-39$ & $300-360 \times 40-56$ & $310-320 \times 39-46$ & $280-300 \times 40-60$ \\
\hline Furcae & $120-150 \times 12$ & $270-290 \times 28-34$ & $219-262 \times 19$ & $300-400 \times 16$ \\
\hline $\begin{array}{l}\text { Flame cell } \\
\text { formula }\end{array}$ & $2[(2+2+2)+(2+2+[2])]=24$ & $2[(2+2+2)+(2+2+[2])]=24$ & $2 \cdot[(3+3+3)+(3+3+[3])]=36$ & $2 \cdot[(3+3+3)+(3+3+[3])]=36$ \\
\hline $\begin{array}{l}1^{\text {st }} \\
\text { intermediate } \\
\text { hosts }\end{array}$ & Bithynia fuchsiana & Boreoelona ussuriensis & Parafossarulus striatulus & $\begin{array}{l}\text { Parafossarulus } \\
\text { manchouricus }\end{array}$ \\
\hline
\end{tabular}




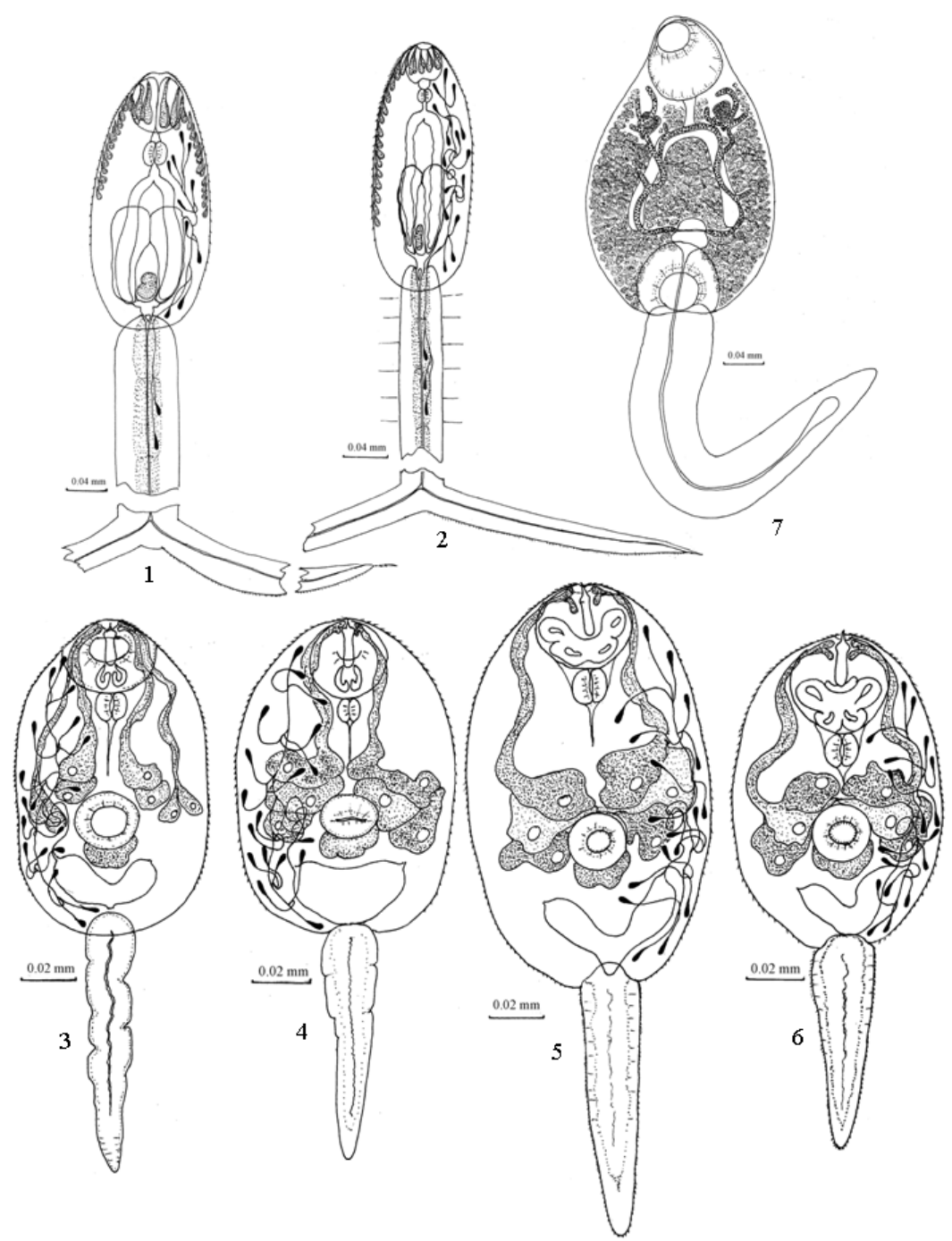

Fig. 1 - 7. Cercariae from North-Vietnamese freshwater snails. 1 - Holostephanus sp. 1; 2 - Holostephanus sp. 2; 3 - Pleurogenidae gen. sp. 1; 4 Pleurogenidae gen. sp. 2; 5 - Acanthatrium sp., 6 - Paralecithodendrium sp., 7 - Paramphistomidae gen. sp.

canals: caudally, two are collected and laterally joined across comissure, and medially, they run from comissure. Last canal divides in two not far from excretory bladder, and both branches enter into it. Caudal canal runs through the tail and furcae and opens at its ends in pores. Tail includes five pairs of caudal bodies. Furcae covered by very small spines.

\section{Holostephanus sp. 2 (Fig. 2; Table 1)}

First intermediate host: Parafossarulus striatulus (1 specimen).

Habitat: rice fields, Nam Dinh province.

Sporocyst: Body thread-shaped with terminal birth pore.

Cercaria: Oval, with ventral body cavity covered by spines at anterior end and on dorsal surface. Anterior organ round; pharynx, short prepharynx and esophagus present. Caeca reach level of middle of excretory bladder. Cercaria has glands in the form of numerous $(19-20)$ cells placed at level of oral organ and laterally along body. Most of these cells $(17-18)$ situated from oral organ to last third of body. Ducts of glands opened at body surface at sites of their disposition. Anlagen of reproductive organs anterior to excretory bladder. Excretory system includes excretory bladder and row of canals: caudal, two collective lateral joined across comissure at level of esophagial bifurcation, and medial, that run from comissure. Last canal divides in two in middle of body, and both branches enter into excretory bladder. Caudal canal runs through tail and furcae and opens at its ends in pores. Tail with $5-6$ pairs of caudal bodies and sensory hairs or sensillae. Furcae covered by small spines.

Remarks: Based on all of their morphological features, including the structure of the excretory system, and the list of their first intermediate hosts, these two cercariae are most similar to species from the genus Holostephanus. Only H. metorchis Yamaguti, 1939 was previously found as a mature stage parasite in hawks (Milvus migrans) in Vietnam (Le, 2000). There are no available data concerning the larvae of this species. H. nipponicus Yamaguti, 1939 and $H$. rallus Tang et Tang, 1989 have been found on other species in East Asia, but the cercariae were described only for H. nipponicus (Komija \& Enomoto, 1967, cit. on: Combes et al., 1980; Besprozvannykh 2003a). In addition, there are unpublished data concerning the life cycle and 
Table 2. Sizes $(\mu \mathrm{m})$ of cercariae Pleurogenidae Looss, 1899

\begin{tabular}{lcccc}
\hline Signs & Pleurogenidae gen. sp. 1 & Pleurogenidae gen. sp. 2 & $\begin{array}{c}\text { Pleurogenoides medians } \\
\text { (in Besprozvannykh, 2000) }\end{array}$ & $\begin{array}{c}\text { Pleurogenoides japonicus } \\
\text { (in Shibue, 1953) }\end{array}$ \\
\hline Body & $108-116 \times 69-77$ & $96-100 \times 77$ & $85-96 \times 48-53$ & $208-244 \times 116-156$ \\
Oral sucker & $23-27 \times 35-39$ & 27 in diameter & 27 in diameter & $48-62 \times 48-60$ \\
Pharynx & 12 in diameter & $8-12$ in diameter & $6-10$ in diameter & - \\
Ventral sucker & $19-23 \times 23-27$ & $0.0154 \times 0.019-0.023$ & $0.015-0.020$ in diameter & $0.030-0.036$ in diameter \\
Stylet & $15-19 \times 4$ & $15-19 \times 4$ & $6-10$ long & $24 \times 8$ \\
Tail & $92-96 \times 15-19$ & $73-85 \times 15-9$ & $53-59 \times 15$ & $88-232 \times 22-32$ \\
$1^{\text {st }}$ intermediate & Bithynia fuchsiana & Parafossarulus & Boreoelona ussuriensis & Parafossarulus misellus \\
hosts & & striatulus & (Erhmann) & (Gredler) \\
\hline
\end{tabular}

cercariae of $H$. cobitidis Opravilova, 1968 from the southern far east of Russia. Cercariae of Holostephanus sp. 1 from Vietnamese Bithynia and $H$. cobitidis from Boreoelona (Russia) exhibit a similar flame cell formula to Holostephanus sp. 2 and H. nipponicus (Table 1). Additionally, all of these cercariae differ in the sizes of their body and furcae but do not show remarkable differences in the sizes of the oral organ, pharynx or tail (Table 1).

The present data on the morphology and sizes of the cercariae of Vietnamese Holostephanus are not sufficient for their exact identification. We now consider them to be independent species.

Family Pleurogenidae Looss, 1899

3. Pleurogenidae gen. sp. 1 (Fig. 3; Table 2)

First intermediate host: Bithynia fuchsiana (1 specimen).

Habitat: rice fields, Nam Dinh province.

Sporocyst. Body sac-shaped.

Cercaria. Body oval, spined. Oral sucker with small $\omega$ shaped virgula and stylet. Stylet with conical point, welldeveloped shoulders and wide trunk. Basal widening absent. Pharynx round, adjoining oral sucker. Esophagus fine; caeca not developed. Ventral sucker smaller than oral sucker, 50 - 62 from anterior end of body. Anlagen of the reproductive organs posterior to ventral sucker. Glands as 4 pairs of cells at level of ventral sucker. First two pairs larger than second two pairs. Ducts of glands opened at anterior end of body. Tail longer than body. Excretory bladder V-shaped. Flame cell formula $2[(3+3+3)+(3+3+3)]=36$.

\section{Pleurogenidae gen. sp. 2 (Fig. 4; Table 2)}

First intermediate host: Parafossarulus striatulus (1 specimen).

Habitat: rice fields, Nam Dinh province.

Sporocyst: Body sac-shaped.

Cercaria: Body oval, spined. Oral sucker with small $\omega$ shaped virgula and stylet. Stylet with conical point, welldeveloped shoulders and wide trunk. Basal widening absent. Pharynx small, adjoining oral sucker. Esophagus fine; caeca non-developed. Ventral sucker smaller than oral sucker and lies 58-65 from anterior end of body. Anlagen of the reproductive organs immediately beyond ventral sucker. Glands of cercaria of three pairs of cells, between esophagus and middle of ventral sucker. First and third pairs have granular structure. Ducts of glands opened at anterior end of body. Tail smaller than body. Excretory bladder V-shaped. Flame cell formula $2[(3+3+3)+(3+3+3)]=36$.

Remarks: The reason for defining the last two species as Pleurogenidae is their morphological likeness with the cercariae of this family. Among the identified cercariae of this family belonging to Nenimandijea Kaw, 1950, Mosesia Travassos, 1928, Parabascus Looss, 1907, Lecithodolfusia (Odening, 1964) and Pleurogenoides Travassos, 1921 (Besprozvannykh, 1994, 2000a, b; 2003b; Ito, 1964; Neuhaus, 1940; Shibue, 1953), by form of the virgula the Vietnamese Pleurogenidae gen. spp. are closest to the Pleurogenoides species: P. medians Olsson, 1876 and $P$. japonicus (Yamaguti, 1936). Earlier, mature $P$. medians were found in amphibian hosts from Europe, Asia, Australia (Prudhoe \& Bray, 1982; Besprozvannykh, 2000a; Düşen \& Öz, 2013), and P. japonicus from Japan (Shibue, 1953). P. medians infects Bithynia and Boreoelona, and P. japonicus infects Parafossarulus. The identified Pleurogenidae are most similar to $P$. medians. Compared to $P$. japonicus, they differ in the smaller size of the body and organs (Table 2).

The cercariae of Pleurogenidae gen. sp. 1 and $P$. medians, described by Neuhaus (1940), have 4 pairs of penetration glands, while those of Pleurogenidae gen. sp. 2 and $P$. medians (Besprozvannykh, 2000a) have 3 pairs. Therefore, for an exact definition of the Vietnamese Pleurogenidae, as for the definition of the taxonomic status of European and Far East $P$. medians, additional investigations, including the collection of genetic data, will be necessary.

In Vietnam, four species of adult trematodes belonging to two subfamilies of Pleurogenidae were found: Pleurogenoides sphaericus (Klein 1905) and Nenimandijea kasmirensis Kaw, 1950 in Rana guentheri Boulenger from Red River delta and Parabascus ovatus (Tubangui, 1928) and Maxbraunium baeri Rohde, 1964 in bats (Le \& Ngo, 2007)

Family Lecithodendriidae Lühe, 1901

5. Acanthatrium sp. (Fig. 5; Table 3)

First intermediate host: Melanoides tuberculata (1 specimen).

Habitat: Red River basin, close to Hanoi.

Sporocyst: Body oval or round.

Cercaria: Body oval, and its surface, including the tail, spined. Oral sucker with butterfly-shaped virgula and sty- 
Table 3. Sizes $(\mu \mathrm{m})$ of cercariae of Acanthathrium and Paralecithodendrium

\begin{tabular}{|c|c|c|c|c|c|}
\hline Signs & Acanthatrium sp. & Paralecithodendrium sp. & $\begin{array}{l}\text { Paralecithodendrium dollfusi } \\
\text { (in Besprozvannykh, 1990) }\end{array}$ & $\begin{array}{c}\text { Acanthatrium ovatum } \\
\text { (in Besprozvannykh, 1990) }\end{array}$ & $\begin{array}{c}\text { Acanthatrium } \\
\text { hitaensis Koga, } 1953 \\
\text { (cit. by Ito, 1964) }\end{array}$ \\
\hline Body & $142-161 \times 85-92$ & $89-112 \times 73-77$ & $67-93 \times 61-80$ & $84-120 \times 56-100$ & $75-100 \times 53-88$ \\
\hline Oral sucker & $27-42 \times 35-39$ & $\begin{array}{c}35-39 \\
\text { in diameter }\end{array}$ & $28-36 \times 27-36$ & $28-44 \times 33-39$ & $35-38 \times 25-30$ \\
\hline Pharynx & $\begin{array}{c}12-15 \\
\text { in diameter }\end{array}$ & $8-15 \times 12-15$ & - & - & $10 \times 12$ \\
\hline $\begin{array}{l}\text { Ventral } \\
\text { sucker }\end{array}$ & $\begin{array}{c}19-23 \\
\text { in diameter }\end{array}$ & $\begin{array}{c}19-23 \\
\text { in diameter }\end{array}$ & $\begin{array}{c}17 \\
\text { in diameter }\end{array}$ & $\begin{array}{c}17-20 \\
\text { in diameter }\end{array}$ & $13-18 \times 13-15$ \\
\hline Stylet & $19-23 \times 4-7$ & $15-19 \times 4-7$ & $14 \times 5$ & $20 \times 6$ & $175 \times 5$ \\
\hline Tail & $104 \times 19$ & $65-89 \times 19$ & $28-46 \times 11-18$ & $33-56 \times 16-22$ & $28-75 \times 18-25$ \\
\hline $\begin{array}{l}1^{\text {st }} \\
\text { intermediate } \\
\text { hosts }\end{array}$ & $\begin{array}{l}\text { Melanoides } \\
\text { tuberculata }\end{array}$ & Melanoides tuberculata & Parajuga spp. & Parajuga spp. & $\begin{array}{l}\text { Semisulcospira } \\
\text { libertina (Gould) }\end{array}$ \\
\hline
\end{tabular}

let. Stylet with conical point and weak-developed shoulders. First half of trunk narrow (equal to wide of point), but second half in 1.5 times wider than $1^{\text {st }}$ half. Basal widening absent. Pharynx round. Caeca non-developed. Ventral sucker with small spines on margin of sticking hole. Distance from anterior end of body to ventral sucker $54-96$. Anlagen of the reproductive organs immediately after ventral sucker. Glands consist of three pairs of cells. First and third pairs are darker. Ducts of glands opened at anterior end of body. Excretory bladder V-shaped. Flame cell formula $2[(3+3+3)+(3+3+3)]=36$.

\section{Paralecithodendrium sp. (Fig. 6; Table 3)}

First intermediate host: Melanoides tuberculata (1 specimen).

Habitat: Red River basin, close to Hanoi.

Sporocyst: Body oval or round.

Cercaria. Body oval, spined, including tail. Oral sucker with butterfly-shaped virgula and stylet. Stylet with conical point and well-developed shoulders. Its trunk narrowed from posterior to anterior end. Basal widening absent. Pharynx oval. Caeca non-developed. Ventral sucker with small spines at margin of sticking hole. Distance from anterior end of body to ventral sucker $54-62$. Anlagen of the reproductive organs immediately after ventral sucker. Glands of three pairs of cells. First and third pairs are darker. Ducts of glands opened at anterior end of body. Excretory bladder $\mathrm{V}$-shaped. Flame cell formula $2[(3+3+3)+(3+3+3)]=36$.

Remarks: The cercariae of Lecithodendriidae identified here were defined as Acanthatrium sp. and Paralecithodendrium sp. because they show morphological similarity to the cercariae of Acanthatrium hitaensis Koga, 1953, A. ovatum Yamaguti, 1993 and Paralecithodendrium dollfusi (Besprozvannykh, 1990). The cercariae of $A$. hitaensis were found in Semisulcospira Boettger from Japan (Ito, 1964), while two other species were found in $\mathrm{Pa}$ rajuga Prozorova et Starobogatov from the Primorsky Region (Southern Far East of Russia) (snails of these genera belong to the order Cerithiformes, such as Melanoides Olivier) (Besprozvannykh, 1990). Specific feature of cercariae of these worms is butterfly-shaped virgula. Morphologically, both Vietnamese Lecithodendriidae differ 194 from the cercariae of $P$. dollfusi and A. ovatum in the absence of a connection between the cells of the $1^{\text {st }}$ pair of glands. Metrically, the cercariae of Acanthatrium sp. exhibit a larger body than those of only one of the other mentioned species (Table 3). At the same time, they similar with $\mathrm{A}$. ovatum by form of stylet. The cercariae of $\mathrm{Pa}$ ralecithodendrium do not show obvious metric differences from the cercariae of $A$. hitaensis and P. dollfusi (Table 3), but have the similar with the last species by form of the stylet.

Among to each other the cercariae of Acanthatrium sp. and Paralecithodendrium sp. differ by form of the stylet and sizes of body, such as the case of Acanthatrium ovatum compared with Paralecithodendrium dollfusi (Besprozvannykh, 1990). For this reason and on the basis of data on the sizes and morphology of the cercariae of Vietnamese Lecithodendriidae, they belong to various genera. A final decision concerning the generic and specific position of Acanthatrium sp. and Paralecithodendrium sp. will be possible after investigation of all developmental stages of these worms.

Our observations showed that the cercariae of Acanthatrium sp. and Paralecithodendrium sp., such those of $A$. ovatum and $P$. dollfusi, can undergo encystment in the environment. However, while the cercariae of $A$. ovatum and $P$. dollfusi have been observed to encyst only under cover glass or in a wad of mucous, many specimens of Vietnamese cercariae encysted immediately prior to death in any setting.

Family Paramphistomidae Fischoeder, 1901

7. Paramphistomidae gen. sp. (Fig. 7)

First intermediate host: Bithynia fuchsiana.

Habitat: rice fields, Nam Dinh province.

Redia: Body bag-shaped with short caecum.

Cercaria: Size of pyramidal brown body with numerous cystogenous glands $300-310 \times 210-270$. Oral sucker 77 -85 in diameter. At level of its posterior margin, there are two eye-spots. Esophagus long. Esophagial bifurcation at level of posterior margin of first third of body. Caeca terminate close to excretory bladder. Ventral sucker $58-77 \times$ $77-81$, at posterior end of body. Excretory bladder Oshaped. Collective canals of excretory system fill with 
small granules. They connected prior to esophagial bifurcation and form a retort-shaped hoop with six branches. Four of them are short: two lateral and two terminal. Two long canals situated between them, each divided into three branches that extend to pigmented eye-spots. Size of tail $450-500 \times 70-77$.

Our observations showed that the cercariae did not encyst on the walls of Petri dishes, as observed for algae. After a short period of swimming, they died.

Remarks: The cercariae were defined as Paramphistomidae on the basis of the structure of the excretory system, specifically based on its collective canals (presence of cross comissure between left and right collective canals and branches of collective canals), which are closest to the cercariae of Calicophoron Näsmark, 1937 and Paramphistomum Fischoeder, 1901 of this family.

Most species of Amphistomida (Luhe, 1909) use various pulmonate snails as their $1^{\text {st }}$ intermediate hosts. Only two species were found in Prosobranchs: Cercaria indicae XXXII Sewell, 1922 (in Amnicola travancorica (Benson) from Pakistan and in Bithynia tentaculata (L.) from India) and Paramphistomid cercaria (in Cleopatra bulimoides (Olivier) from Egypt) (Sey, 2000). Pulmonate snails have also been found to serve as intermediate hosts for these species. Cercaria indicae XXXII was described from $\mathrm{Bu}$ limus pulchellus Shuttleworth, and later, cercariae from

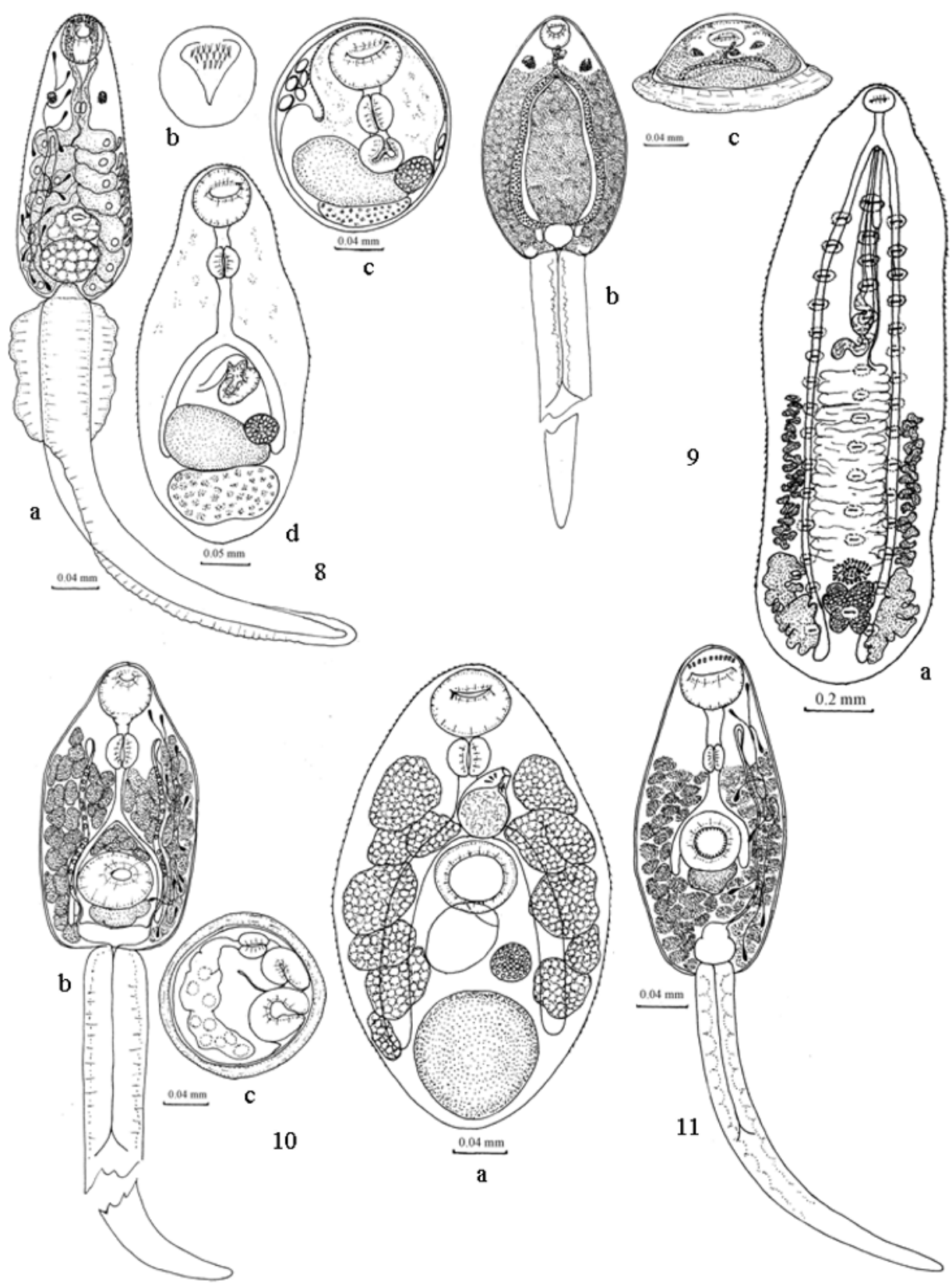

Fig. 8 - 11. Worms from North Vietnam. 8 - Haplorchis sp.: a - cercaria, b - spines of oral sucker, c - metacercaria in cyst, d-metacercaria without cyst; 9 -Notocotylus intestinalis Tubangui, 1932: a - adult worm, b - cercaria, c-metacercaria; 10 - Sphaeridiotrema monorchis Xiumin et Qingquan, 1983: a - adult worm; b - cercaria; c - metacercaria; 11 - cercaria of Microparyphium sp. 
Prosobranchs were attributed to Cercaria indicae XXXI. Specimens of Paramphistomid cercaria were found in Prosobranchia, and subsequently cercariae from Bulinus Müller and Planorbis Müller (Sey, 2000) were attached to its. We cannot define the specific positions of all of these cercariae.

Family Heterophyidae Leiper, 1909

8. Haplorchis sp. (Fig. 8 a, b, c, d; Table 4, 5)

First intermediate host: Melanoides tuberculata (1 specimen).

Second intermediate host: Phoxinus perenurus mantschuricus (determined experimentally).

Habitat: Red River basin, close to Hanoi.

Site of metacercariae: gravel tissue of gills, muscles along spine.

Redia: Size of bag-shaped body 239 - 308 x $81-104$. Pharynx $39-58$ x $39-54$. Caecum short.

Cercaria: Body pyramidal, with light-brown pigmentation, covered by small spines. Two small eye-spots are present on dorsal side of $1^{\text {st }}$ third of body. Oral sucker subterminal. In cavity on the dorsal wall, three rows of spines are present (5-7-9). Pharynx small and usually covered by the ducts of glands. Caeca non-developed. Ventral sucker not fully formed. Anlagen of reproductive organs on dorsal side of it. From posterior margin of $1^{\text {st }}$ third of body to end of body, there are 14 penetrative glands-cells. Its ducts opened ahead of oral sucker according to formula $3+4+4+3$. At this site, $20-30$ cystogenous gland cells are present. Tail with membrane laterally in $1^{\text {st }}$ third and dorso-ventrally on other parts. Excretory bladder Oshaped. Flame cell formula $2[(3+3)+(3+3+3)]=30$.

Metacercaria: Cyst oval; its walls $3.9-7.7$ in thickness. Free space in cyst filled with concreciae in form of oval plates. Body of larva covered by spines and contains mosaic granules of brown pigment. Oral sucker subterminal. Prepharynx short (19 long). Pharynx present. Esophagus 58 long. Esophagial bifurcation prior to ventrogenital complex. Caeca reach level between anterior margin and middle of testis. Gland cells opened at anterior end of body and are situated lateral to pharynx and esophagus. Genital pore and genital sinus of ventrogenital complex exhibit chitin plates or spines. Anlagen of ovary situated posterior to ventrogenital complex, to right of median line. Anlagen of testis egg-shaped, between anlagen of ovary and excretory bladder. Excretory bladder filled with granules.

Life cycle: Our experiments showed that the cercariae of Haplorchis sp. actively penetrate fishes (we used 6 specimens of Phoxnus perenurus mantschuricus in our experiments) and are found mainly in the gravel tissue of the gills and in the muscles along the spine. The intensity of infection was 5-14 larvae per fish. On the $50^{\text {th }}$ day, the infected fishes were fed to a rat. When this animal was dissected (on the $7^{\text {th }}$ day after infection), no parasites were found.

Remarks: A total of 3 species belonging to Haplorchis have been found in Vietnam to date: H. pumilio Looss, 1896, H. yokogawai (Katzuta, 1932) and H. taichui
(Nishigori, 1924). The first intermediate hosts (snails from the genera Tarebia, Melanoides and Stenomilania) and second intermediate hosts (freshwater fishes) of these species have been defined. Descriptions of their larvae have been published (Scholz et al., 1991; Ditrich et al., 1992; Skov et al., 2009). The cercaria found in Melanoides are larger than $H$. yokogawai and $H$ taichui (Table 4$)$ with regard to the size of the body and all organs. Metacercariae Haplorchis sp. differ from H. taichui in their smaller cysts, larger ovary and testis and additional chitin plates on the ventrogenital complex (Table 5). The cercariae of Haplorchis sp. differ from the $H$. pumilio specimens found by Skov et al. (2009) in Melanoides from Laos (Table 4). The metacercariae of Haplorchis sp. and H. pumilio (from fishes in Laos) are similar metrically except for the sizes of their sex organs (Scholz et al., 1991; Skov et al., 2009) (Table 5). The highest similarity of Haplorchis sp. in terms of the size of the cercariae and metacercariae is found with H. pumilio from Melanoides, found in Venezuela (Diaz et al., 2008). Diaz and coauthors defined species of worms based on the morphology of adult parasites. Their experiments performed for the definition of possible definitive hosts were positive only for infections in ducks. Rats, mice and chickens were not infected. We obtained the same results. However, based on data reported by Morozov (1952), H. pumilio can infect birds such as well as mammals, including Carnivornia. We believe that the identified worms from the genus Haplorchis do not belong to $H$. yokogawai, $H$ taichui or $H$. pumilio. It is possible that the worms defined as $H$. pumilio from Venezuela belong to another species.

Family Notocotylidae Lühe, 1909

9. Notocotylus intestinalis Tubangui, 1932 (Fig. 9 a, b, c; Fig. 13 a, b, c)

First intermediate host: Parafossarulus striatulus (4 specimens).

Habitat: rice fields, Nam Dinh province.

Definitive host: chicken, Gallus gallus dom. (determined experimentally).

Site of adult worms: caecum.

Representative sequences: JQ890559 - JQ890563 (28S rDNA); no intraspecific variation detected.

Adult worm: Body 1680 - 1790 x 500 - 540, covered by spines (thicker at anterior end of body) up to level of middle of vitellaria. Ventral glands situated in three longitudinal rows according to formula 16 (15) $16+1 / 2$. Middle row from 15 glands, and lateral rows from 16 glands. Oral sucker $50-77$ x 73 - 92. Esophagus 58 - 73 long. Caeca reach posterior margin of testes. Two deep-lobed (with small lobes) testes lie parallel to each other, close to posterior end of body to left and right of median line of body. Sizes of testes $196-231 \times 116-123$ and $169-231 \times 96-$ 119. Cirrus sac $50-58 \times 54-58$. Seminal vesicle from two parts: internal (in bursa) and external. Genital pore on median line immediately after esophagial bifurcation. Cirrus non-armed. Lobed ovary of $96-154 \times 116-154$, on median line between testes at level of its center. Mehlis' 


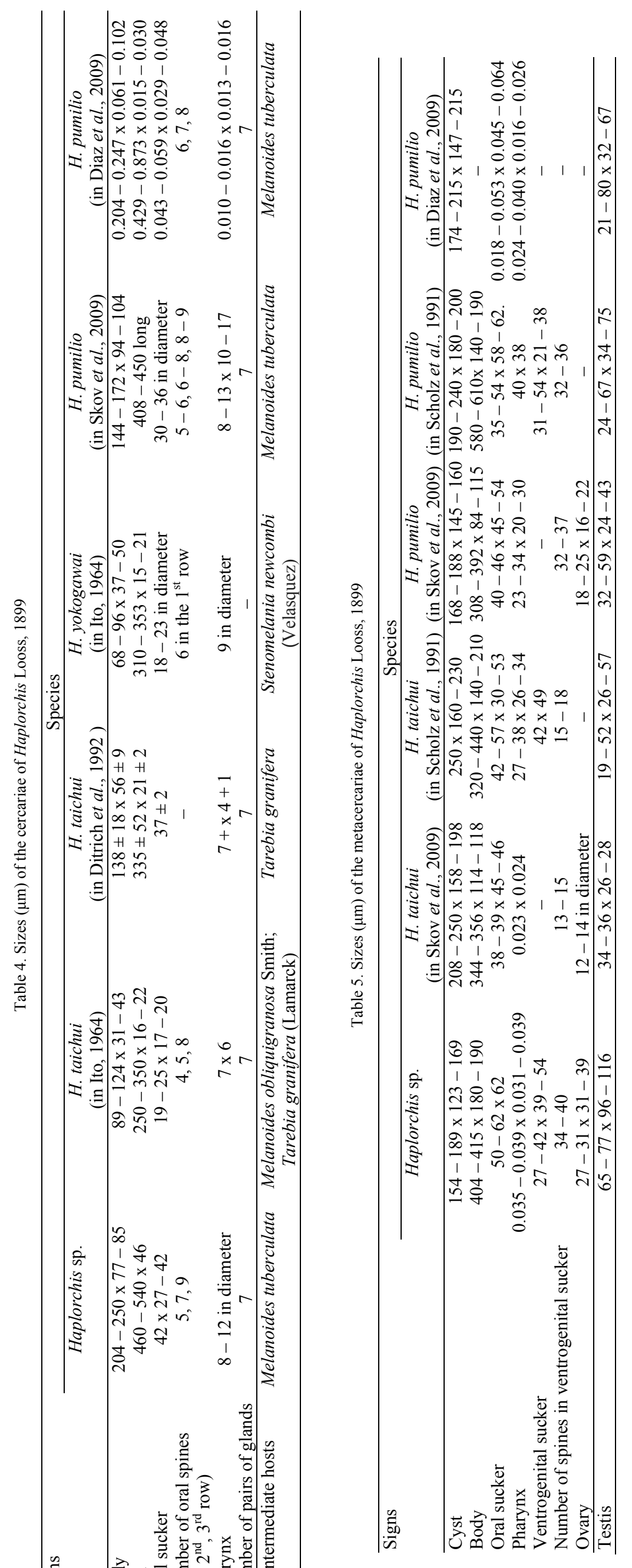


gland $58-62 \times 96-100$, in front of ovary. Loops of uterus do not cover the caeca. Metraterm 240 - 250 long. Vitellaria situated laterally, 850 - 890 from anterior end of body, and are $460-590$ long. Sizes of eggs without filaments $19-23 \times 12-15$.

Redia: Body $640-760 \times 200-240$. Pharynx $56-67 \times 67$ -78 . Long caecum filled with foodstuffs. Birth pore situated at level of posterior margin of pharynx.

Cercaria: Body 203 - 235 x 127 - 135, with numerous cystogenous glands. Three eye-spots at anterior end of body at level of esophagus. Middle eye smaller and lighter than lateral ones. Oral sucker $27-31$ in diameter. Caeca reach level of middle of excretory bladder, which has a round form. Collective canals of excretory system form a ring, connecting at level of esophagial bifurcation. Single branch, with numerous granules and equal to esophagus in length, departs from place of connection. Caudal canal in distal part of tail divided into two short branches that open into pores. In posterior end of body, there are two branches, which used by cercariae for movement on substrate. Tail $397-560 \times 44-56$.

Metacercaria: Cyst cupola-shaped, 166 - 177 in diameter. Life cycle: Metacercariae of $N$. intestinalis were fed to two chickens (100 specimens to each). After 14 days, in the appendices of both birds, adult worms (13 specimens in one and 17 specimens in the other).

Remarks: N. intestinalis was described from birds in Philippines (Skrjabin, 1953) and was later found in Vietnam (Le, 2000). In 2010, as established during experimental investigations, these worms are found in the southern Far East of Russia, and their $1^{\text {st }}$ intermediate hosts are snails from the genus Parafossarulus (Besprozvannykh, 2010). The descriptions of these worms based on a set of morphological characters (e.g., the number and position of ventral glands on the surface of adult worms: 16 (15) $16+$ $1 / 2$; the structure of the testes (deep-lobed, lobes are small); the presence of branches in the collective canals of the excretory system) are identical to those reported for specimens of $N$. intestinalis from the Russian Far East and the Philippines.

Family Psilostomidae Looss, 1900

10. Sphaeridiotrema monorchis Xiumin et Qingquan, 1983 (Fig.. 10 a, b, c; Fig. 13 d, e, f; Table 6)

First intermediate host: Parafossarulus striatulus (3 specimen)

Habitat: rice fields, Nam Dinh province.

Second intermediate hosts: Parafossarulus spiridonovi, Boreoelona ussuriensis (determined experimentally).

Site: tissue of the mantle.

Representative sequences: JQ890544 - JQ890548 (28S rDNA); no intraspecific variation detected.

Definitive host: duck, Gallus gallus dom. (determined experimentally).

Site: small intestine.

Adult worm: Body oval, covered by spines (on ventral side, from anterior end of body to level of center of testis; and on dorsal side, up to level of posterior margin of ventral sucker). Oral sucker subterminal. Prepharynx absent, but pharynx present. Esophagus short. Esophagial bifurcation anterior to ventral sucker. Caeca reach level of mid-level of testis. Ventral sucker somewhat larger than oral sucker. A single testis at posterior end of body. Round ovary sinistral, between ventral sucker and testis. Cirrus sac in form of a comma, contains seminal vesicle и prostatic cells and situated at level of distance: posterior margin of pharynx eosphagial bifurcation. Genital pore sinistrale. Vitellarium formed by $6-8$ large follicles on each side extended from esophagial bifurcation up to middle level of testis. Two first follicles can be confluent anterior to ventral sucker. Uterus usually with $1-2$ light yellow eggs.

Redia: Body $560-950 \times 150-290$. Pharynx $39-56 \times 40$ -65 . Caecum reach middle of body, yellow-black masses. Cercaria: Body leaf-shaped and, due to numerous cysto-

Table 6. Sizes ( $\mu \mathrm{m})$ of Sphaeridiotrema monorchis Xiumin et Qingquan, 1983

\begin{tabular}{|c|c|c|c|}
\hline \multirow[t]{2}{*}{ Signs } & \multirow{2}{*}{$\begin{array}{l}\text { S. monorchis } \\
\text { (in Xiumin et Qingquan, 1983) }\end{array}$} & S. monorchis from Primorsky Region & S. monorchis from Vietnam \\
\hline & & \multicolumn{2}{|l|}{ our data } \\
\hline \multicolumn{4}{|c|}{ adult worms } \\
\hline Body & $314-476 \times 209-314$ & $290-340 \times 190-210$ & $327-354 \times 212-273$ \\
\hline Oral sucker & $48-76 \times 54-85$ & $42-54 \times 58-65$ & $46-54 \times 46-50$ \\
\hline Pharynx & $36-51 \times 36-59$ & $23-35 \times 27-42$ & $31-39 \times 23-31$ \\
\hline Ventral sucker & $57-88 \times 59-88$ & $56-62$ in diameter & $58-69 \times 58-65$ \\
\hline Testis & $71-119 \times 85-123$ & $80-97 \times 76-96$ & $89-104 \times 96-116$ \\
\hline Ovary & $34-78 \times 43-107$ & $32-84 \times 38-60$ & $35-65$ in diameter \\
\hline Cirrus sac & $55-95 \times 43-54$ & $61-80 \times 22-32$ & $77-89 \times 39-69$ \\
\hline Eggs & $95-108 \times 69-83$ & $62 \times 50$ & $60-89 \times 46-50$ \\
\hline \multicolumn{4}{|c|}{ cercariae } \\
\hline Body & $214-274 \times 142-202$ & $250-340 \times 160-260$ & $250-281 \times 135-173$ \\
\hline Oral sucker & $45-51 \times 45-64$ & $50-67$ in diameter & $46-54 \times 46-50$ \\
\hline Pharynx & $28-34 \times 24-33$ & $31-42 \times 24-44$ & $31-39 \times 23-31$ \\
\hline Ventral sucker & $57-59 \times 61-71$ & $45-62 \times 62-78$ & $50-65 \times 65-81$ \\
\hline Tail & $238-360 \times 36-60$ & $240-330 \times 33-56$ & $420-500 \times 46-54$ \\
\hline $1^{\text {st }}$ intermediate hosts & Parafossarulus striatulus & Parafossarulus manchouricus (Biurguinat) & Parafossarulus striatulus \\
\hline \multicolumn{4}{|c|}{ metacercariae } \\
\hline Cyst & $143-165 \times 145-175$ & $160-168 \times 148-154$ & $150-158$ in diameter \\
\hline
\end{tabular}


genous glands, opaque and covered by secretory case. Oral sucker subterminal. Short prepharynx and pharynx present. Esophagus does not extend to anterior end of ventral sucker. Caeca terminate closely to excretory bladder. Ventral sucker 166 - 185 from anterior end of body. Cystogenous glands in space from level of pharynx to posterior end of body. Anlagen of reproductive organs between ventral sucker and excretory bladder. Excretory bladder Vshaped. Collective canals of excretory system with $15-20$ small granules, extending to level of pharynx. Caudal excretory canal opens into two pores in middle of tail. Flame cell formula $2[(2+2+2)+(2+2+2)]=24$. Tail well developed, with a length that almost twice that of body.

Metacercaria: Cyst $150-158$ in diameter, and thickness of wall 12 . Oral sucker $35-50 \times 34-54$. Pharynx $27-35$ $\times 23-35$. Ventral sucker $46-62 \times 50-58$. Collective canals of excretory system with $8-10$ granules each.

Life cycle: It was established experimentally that the cercaria penetrate under the shells of the snails Parafossarulus spiridonovi and Boreoelona ussuriensis and become encysted in the tissues of the mantle. We also attempted to infect Lymnaea ussuriensis and Anisus centrifugops, but they remained free from infection. On the $25^{\text {th }}$ day after the beginning of the experiment, infected snails were fed to ducks, and 7 days later, we observed adult Sphaeridiotrema monorchis in the duck's intestine.

Remarks: Sphaeridiotrema monorchis was first found in China, where its life cycle and all stages of its development were studied (Xiumin \& Qingquan, 1983). Xiumin and Qingquan first defined the intermediate host of this worm (the snail Parafossarulus manchouricus). Similar data, with respect to the morphology and biology of this species from the territory of the Primorsky Region, were obtained in the present study (data are in press). The flukes found in Vietnam are identical in terms of their morphology, the sizes of all developmental stages and the list of intermediate hosts to $S$. monorchis described from China and Russia.

Family Echinostomatidae Looss, 1899

11. Microparyphium sp. (Fig. 11)

First intermediate host: Melanoides tuberculata (1 specimen).

Habitat: Red River basin, close to Hanoi.

Second intermediate host: Pseudorasbora parva.

Site: gills.

Redia: Body $440-480 \times 139-154$. Pharynx $73-85 \times 54$

-65 . Caecum exhibits yellow contents, long and reach by lateral branches.

Cercaria: Body 219 - 269 x 104 - 134, non-spined, but covered by fine secretory case. Adoral disk absent. Oral sucker $46-56$ in diameter. On dorsal side, there are ten small cuticular plates. Pharynx $23 \times 154$. Prepharynx and esophagus present. Caeca reach level of posterior margin of ventral sucker. Ventral sucker $42-50 \times 46-50$, surrounded by 32 cuticular plates. Anlagen of reproductive organs immediately after ventral sucker. Distance from anterior end of body to ventral sucker 123 - 135. Numerous cystogenous glands surround all of space outside of main collective canals, which contain scarce granules. Tail $320-335 \times 270$. Excretory bladder with two chambers. Flame cell formula $2[(3+1+1)+(3)]=16$.

It was established experimentally, that cercariae of Microparyphium sp. become encysted in the gills of fishes. Development of this species to the infective stage was not observed.

Remarks: The identified cercariae may belong to Microparyphium kyushuensis Koga, 1952, as worms of this species exhibit a similar morphology (including the same number of cuticular plates on the suckers) to these cercariae and similar body and organ sizes (suckers and pharynx). However, the Vietnamese larvae differ from $M$. kyushuensis in their smaller tail size (Ito, 1964; Besprozvannykh, 2000b).

12. Echinochasmus japonicus Tanabe, 1926 (Fig. 12 a, b, c; Fig. 13 g, h, i; Table 7, 8)

Definitive host: chicken Gallus gallus dom. (determined experimentally).

Site: small intestine.

Representative sequences: JQ890579 - JQ890583 (28S

rDNA); no intraspecific variation detected.

First intermediate host: Parafossarulus striatulus (3 specimens).

Habitat: rice fields, Nam Dinh province.

Second intermediate hosts: the fishes Rhodeus sericeus sericeus and Pseudorasbora parva (determined experimentally) and the snail Parafossarulus striatulus that are infected by parthenitae of E. japonicus.

Site: in fishes - gills, in snails - internal organ tissues.

Adult worm: Body covered by scarce spines. Oral sucker surrounded by adoral disk with 24 spines situated in single row. Angular spines (three on each side of adoral disk) shorter than marginal ones. Width of adoral disk $73-96$. Prepharynx, pear-shaped pharynx and esophagus present. Caeca reach posterior end of body. Ventral sucker 220 243 from anterior end of body. Ovary round, to right of median line of body between $1^{\text {st }}$ testis and ventral sucker. Seminal receptacle and vitellaium reservoirs in middle of body anterior to $1^{\text {st }}$ testis. Testes cross-oval and lie one behind another. Cirrus sac in dorsal position of worms found between the intestinal bifurcation and anterior margin of ventral sucker and partly covered by posterior end of cirrus sac (in this case, genital pore appears to be behind bifurcation). However, in the lateral position of worms, it can be observed that there is a fine channel opening close to anterior margin of ventral sucker, extending away from broadened part of cirrus sac. Cirrus sac with bipartite seminal vesicle. Vitellaria situated in space from anterior end or middle of ventral sucker to posterior end of body. Behind testes, fields of vittelaria are divided by interval. Excretory bladder Y-shaped.

Redia: Body of exinostomatid type, $520-920 \times 169-$ 200. Pharynx $42-46$. The caecum extends to level of locomotor branches.

Cercaria: Body $112-142 \times 65-85$, non-spined and covered by fine secretory case. Oral sucker $27-31 \times 35-39$. 


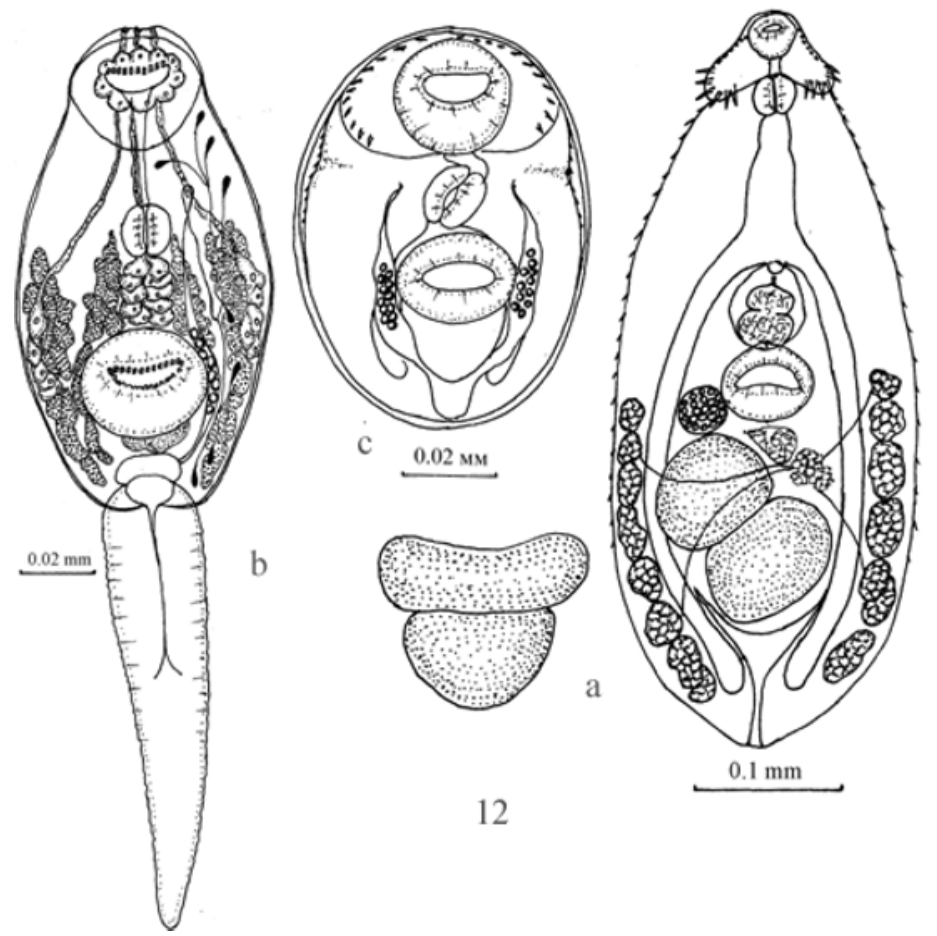

Fig. 12. Echinochasmus japonicus Tanabe, 1926: a - adult worm and variant of position and form of testes, $\mathrm{b}-\mathrm{cercaria}, \mathrm{c}-\mathrm{metacercaria}$

Opening of oral sucker surrounded by a scalloped cuticular formation containing 10 cuticular plates. Pharynx $12-15$ in diameter and situated between oral and ventral suckers. Prepharynx, esophagus and short caeca, contacted by middle of ventral sucker, present. Ventral sucker $23-35 \times 35$ $-39,81-116$ from anterior end of body. On internal margin, ventral sucker has cuticular plates. Anlagen of reproductive organs posterior to ventral sucker. Cystogenous glands situated from level of pharynx up to posterior end of body. In addition to these glands, another type is present: $5-6$ pairs of cells surround the esophagus, and five pairs lie laterally, in middle of body. Ducts of these glands opened at anterior end of body into four groups of pores. Flame cell formula $2[(3+1+1)+(3)]=16$. Excretory bladder has two chambers. Caudal chamber smaller than chamber situated in body. Collective canals of excretory system with $8-10$ granules. Tail $116-123 \times 25-27$.

Metacercaria: Cyst $67-75 \times 61-67$. Body of larva covered by small spines and fills all of free space in cyst. Oral sucker $20-23 \times 24-25$, surrounded by adoral disk with 24 spines. Prepharynx short. Pharynx $13-17 \times 10-15$. Caeca reach excretory bladder. Ventral sucker $17-25$. Each collective canal of excretory system contains $10-12$ granules.

Life cycle: The cycle of development of separate specimens of this species from the same $1^{\text {st }}$ intermediate host can either be continued in fishes as $2^{\text {nd }}$ intermediate hosts or undergo a shorter variation. In the first case, some of the cercariae exit the $1^{\text {st }}$ intermediate host and actively swim in water. When fish breathe, the cercariae can enter the gill cavity and become encysted in the gill's petals. In the second case, the cercariae do not leave the $1^{\text {st }}$ intermediate host and become encysted in its tissues. In experiments, the gills of fishes containing 27-day-old larvae of E. japonicus and snails infected with partenithae were fed (separately) to two chickens. After seven days, we dissected these birds and found seven and 17 specimens of adult worms in the first and second chicken, respectively.

Remarks: The worms described herein are highly similar to Echinochasmus japonicus and E. beleocephalus (Linstow, 1873 ) in all stages of their life cycle (Table 7). E. japonicus was first found in Japan, where its life cycle was studied, and all stages of its development were described (Skrjabin \& Baschkirova, 1956; Ito, 1964; Komiya, 1965). Adult worms of this species have been found in Vietnam (Le, 2000). Several years ago, the life cycle of this species was studied in West Siberian (Filimonova, 1973 - 1974) and in Primorsky Region of Russia (Besprozvannykh, 2009). It was established that the development of E. japonicus takes place using snails from the genus Parafossarulus as the $1^{\text {st }}$ intermediate host and either using fishes and tadpoles as the $2^{\text {nd }}$ intermediate hosts or going through a shorter life cycle variant with a single intermediate host (snails). Adult E. beleocephalus were found in birds in Europe (Skrjabin \& Baschkirova, 1956) and in the Primorsky Region (Oschmarin \& Dozenko, 1951; Besprozvannykh, 2009). The life cycle of this parasite was studied by Karmanova (1974) and Besprozvannykh (2009) in the European part of Russia and in the Primorsky Region of Russia, respectively. It was established that the role of the $1^{\text {st }}$ intermediate host is played by the snails Bithynia tentaculata and Boreoelona ussuriensis. The development of 


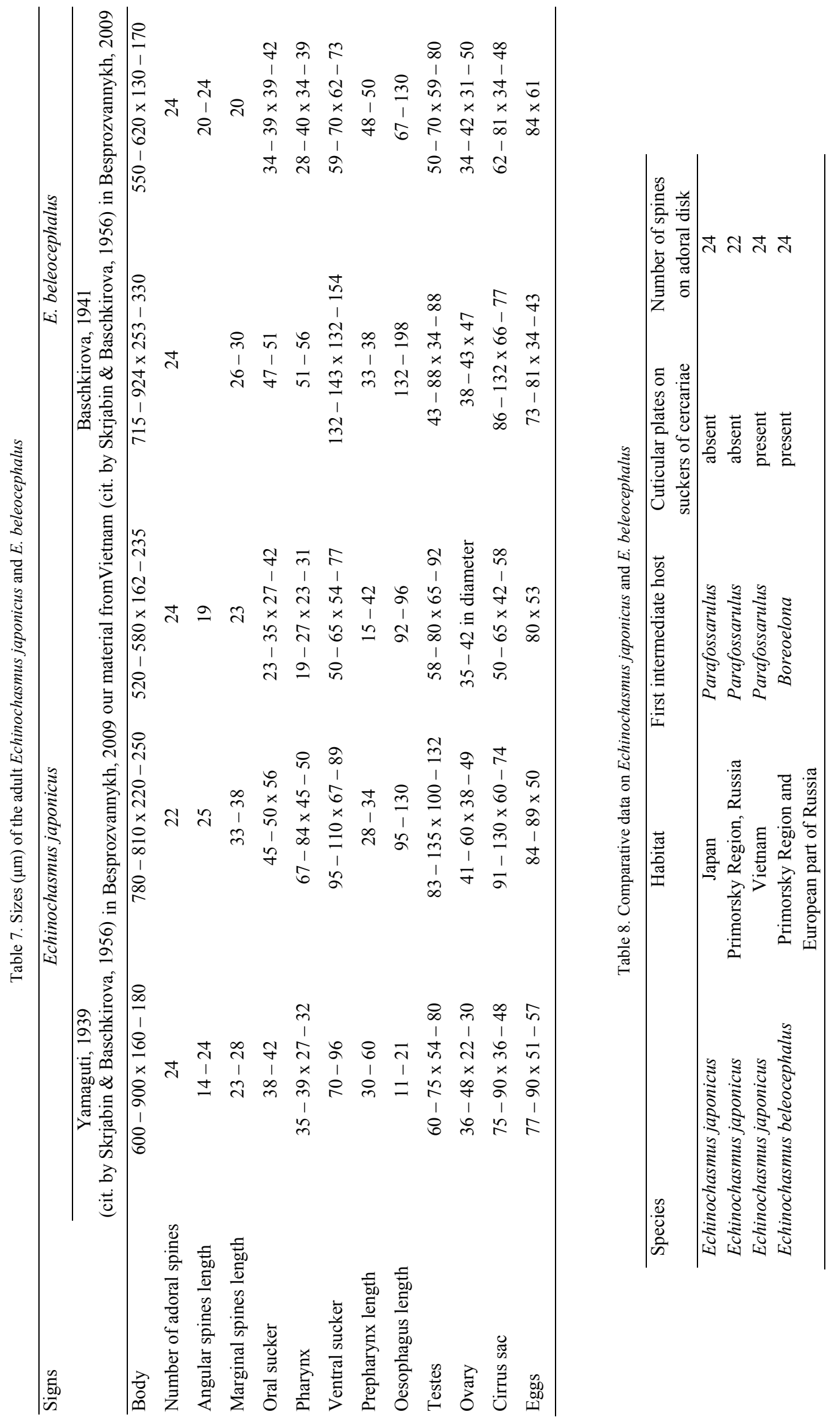




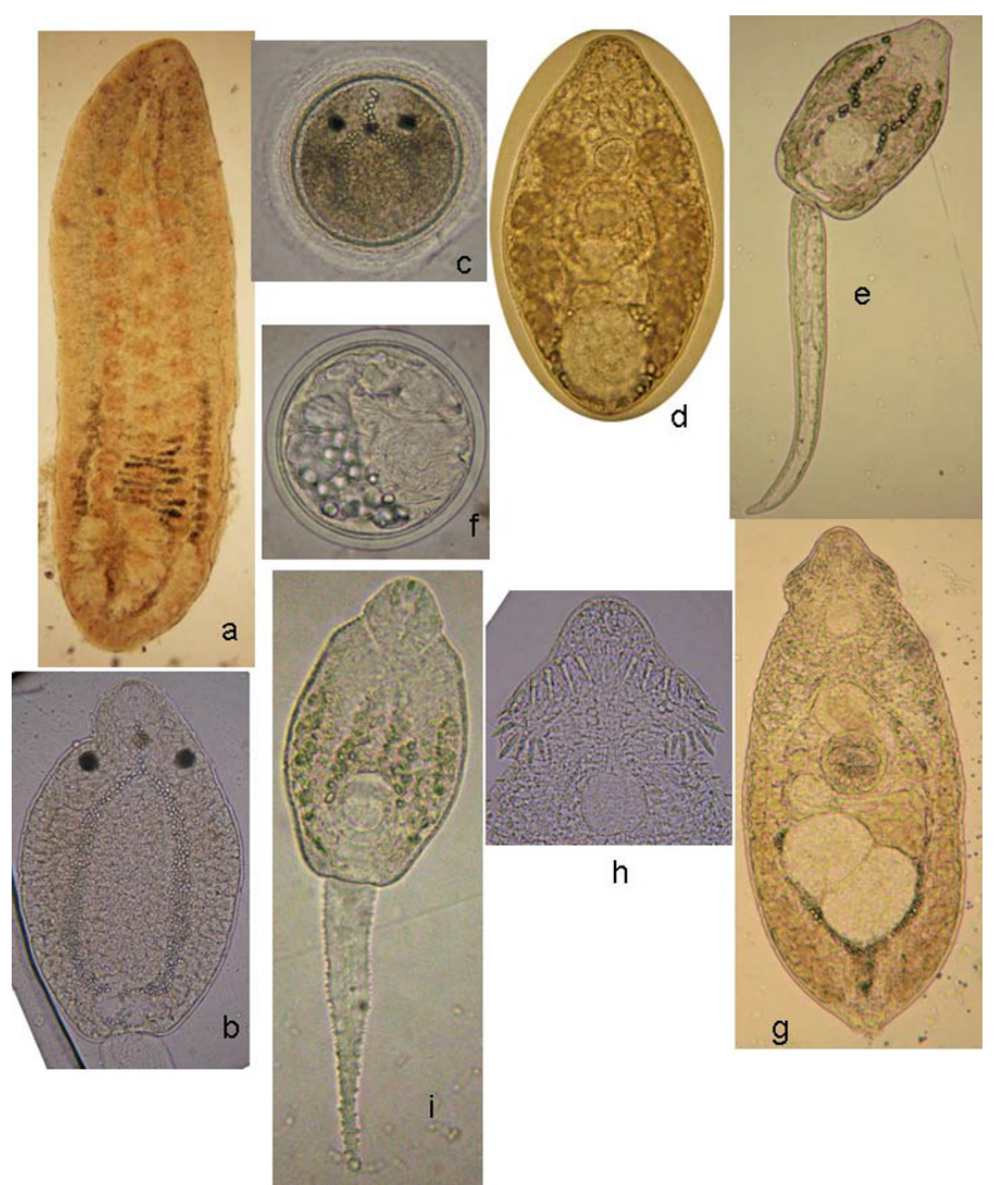

Fig. 13. Worm on various stages of life cycles. Notocotylus intestinalis Tubangui, 1932: a - adult worm, b - cercaria, c - metacercaria; Sphaeridiotrema monorchis Xiumin et Qingquan, 1983: d - adult worm, e - cercaria, f - metacercaria; Echinochasmus japonicus Tanabe, 1926: $\mathrm{g}$ - adult worm, $\mathrm{h}$ - adoral disk, $\mathrm{i}$ - cercaria

E. beleocephalus up to the mature stage is similar to that of E. japonicus. The definition of Vietnamese Echinochasmus was established on the basis of morphological and metrical similarities of adult worms with E. japonicus, described by Yamaguti (Table 7) and the use of Parafossarulus as the $1^{\text {st }}$ intermediate host (Table 8). However, in the cercaria stage, this parasite is similar to Echinochasmus beleocephalus in exhibiting cuticular plates on its suckers (Table 8 ). The specimens of flukes found in the Primorsky Region defined as E. japonicus differ from specimens of the same species from Japan by the number of spines on the adoral disk. However, the cercariae of the two species are identical and develop using Parafossarulus as a host. Therefore, we are of the opinion that these worms belong to three or more similar species that are difficult to differentiate based on morphology. To define the species status of these parasites, genetic data are necessary. It is possible that crossinfection of the $1^{\text {st }}$ intermediate hosts will be sufficient, but this will be difficult to achieve. Until a final decision is made regarding this question, we attribute the parasite from Vietnam to E. japonicus on the basis of the morpho$\operatorname{logy}$ of adult worms and the list of its $1^{\text {st }}$ intermediate hosts.

\section{Conclusion}

In a result of our investigations, we found 12 digenean species from eight families (Cyathocotylidae, Pleurogeni- 
dae, Lecithodendriidae, Paramphistomidae, Heterophyidae, Notocotylidae, Psilostomidae and Echinostomatidae) in freshwater prosobranchial snails: B. fuchsiana, P. striatulus и M. tuberculata. Data on the life cycles of three species (Echinochasmus japonicus, Notocotylus intestinalis and Sphaeridiotrema monorchis) as well as molecular data on $28 \mathrm{~S}$ rDNA were obtained.

\section{References}

BesprozvannyKh, V. V. (1990): [Life cycles of Prosthodendrium dollfusi sp.n. and Acanthathrium ovatum (Trematoda: Lecithodendriidae) in conditions of southern Far East of USSR]. Parazitologia, 24 (5): 431 - 439 (In Russian)

BesprozVAnNyKh, V. V. (1994): [Life cycle of Mosesia longicirrus sp.n. (Trematoda: Lecithodendriidae) in conditions of southern Far East of Russia] Parazitologia, 28 (2): 99 - 104 (In Russian)

BEsPROZVANNYKH, V. V. (2000a): [Biology of trematodes Nenimandijea kashmirensis Kaw, 1950 and Pleurogenoides medians Olsson, 1876 (Pleurogenidae), parasites of frogs, in conditions of Primorsky Region]. Parazitologia, 34 (4): 349 - 353 (In Russian)

BESPROZVANNYKH, V. V. (2000b): [Fauna, biology, ecology of parthenitae and cercariae of trematodes from snails genus Juga (Pachychilidae) in rivers of Primorsky Region] Vladivostok: Dalnauka Publishing, 120 pp. (In Russian)

BESPROZVANNYKH, V. V. (2003a): [Life cycle of digenean Holostephanus nipponicus Yamaguti, 1939 (Cyathocotylidae) in conditions of Primorsky Region]. Parasitologia. 37 (4) 346 - 351 (In Russian)

BESPROZVANNYKH, V. V. (2003b): [Trematoda Lecithodolfusia anatina Khotenovsky, 1967 (Pleurogenidae) and its life cycle in conditions of Primorsky Region]. Parazitologia, 37 (2): 154 - 158 (In Russian)

BESPROZVANNYKH, V. V. (2009): [Life cycles of trematodes Echinochasmus japonicus and E. beleocephalus (Echinostomatidae) in conditions of Primorsky Region]. Parazitologia, 43 (3): 248 - 258 (In Russian)

BESPROZVANNYKH, V. V. (2010): Life cycle of the trematode Notocotylus intestinalis (Digenea, Notocotylidae) under natural conditions in Primorye Region (Russia). Vestnik zoologii, 44 (3): 33 - 36. DOI: 10.2478/v10058010-0016-8.

Combes, C., Albaret, J-L., Arvy, L., Bartoli, P., Bayssage-Dufour, C., Deblock, S., Durette-Desset, M-C., Gabrion, C., Jourdane, J., Lambert, A., Leger, N., Malliard, C. (1980): Atlas mondial des Cercaires. Mem. Mus. nat. hist. Natur. A, 115: $1-236$

Díaz, M. T., Hernandez, L. E., ABUl, K. B. (2008): Studies on the life cycle of Haplorchis pumilio (Looss, 1896) (Trematoda: Heterophyidae) in Venezuela. Revista Científica, FCV-LUZ. XVIII (1): $35-42$

Ditrich, O., Nasincova, V., Scholz, T., Giboda, J. (1992): Larval stages of medically important flukes (Trematoda) from Vientiane province, Laos. Part II. Cercariae
Ann. Parasitol. Hum. Comp., 67 (3): 75 - 81. DOI: 10.1590/S0074-02761992000100003.

DüŞEN, S., Öz, M. (2013): Helminth fauna of the Eurasian Marsh Frog, Pelophylax ridibundus (Pallas, 1771) (Anura: Ranidae), collected from Denizli Province, Inner-West Anatolia Region, Turkey. Helminthologia, 50 (1): 57 - 66. DOI: $10.2478 / \mathrm{s} 11687-013-0108-4$.

FiLimONOVA, L. V. (1973 - 1974): [On the biology of Echinochasmus (Ech.) japonicus Tanabe, 1926 (Trematoda: Echinostomatidae)]. Helminthologia, $14-15$ (1 - 4): 653 - 660 (In Russian)

GINETSINSKAYA, T. A. (1968): [Trematodes, their life cycles, biology and evolution]. M.-L.: Nauka Publishing: 411 pp. (In Russian)

ITO, I. (1964): A monograph of cercariae in Japan and adjacent territories. Progr. Med. Parasitol. Jap. Tokyo, Japan: Meguro Parasitological Museum Tokyo Publishing, 1: $395-550$

KARMANOVA, E. M. (1974): [To knowledge life cycles of Echinochasmus coaxatus Dietz, 1909 and E. beleocephalus (Linstow, 1873) (Echinostomatidae)]. Trudy GELAN, 24: 46 - 53 (In Russian)

KomiJA, Y. (1965): Metacercaria in Japan and adjacent territories. Progr. Med. Parasitol Jap. Tokyo, Japan: Meguro Parasitological Museum Tokyo Publishing, 2: 1 - 328 LE, N. T. (2000): The trematodes parasitic in man and animals (Fauna of Vietnam). Hanoi: Science and Technology Publishing House, 8: 385 pp. (In Vietnamese)

LE, N. T., DoAnh, P. N., The, D. T. (2000): Trematode larvae in the snail Parafossarulus striatulus (Bithyniidae) collected from BaVi and NgocTao areas of HaTay. J. Biol., 22: 15 - 21 (in Vietnamese with English abstract)

LE, N. T., NGO, H. D. (2007): The trematodes parasitic in man and animals. Fauna of Vietnam. Hanoi: Science and Technology Publishing House, 23: 314 pp. (In Vietnamese)

LE, N. T., THE, D. T. (1993): The larvae of trematodes in the species of snail belonging to families Pilidae and Viviparidae in Ha Tay and Hoa Binh Provinces. In: Research work collection on Ecology and Biological Resources (1990 - 1992). Hanoi: Science and Technology Publishing House: 318 - 323 (In Vietnamese with English abstract)

LE, N. T., THE, D. T., NGAI, D. D. (1990): Examination of freshwater snails as intermediate hosts of trematodes, causing trematodosis in poultry. In: Research work collection on Ecology and Biological Resources. Hanoi: Science and Technology Publishing House: 164 - 169 (In Vietnamese with English abstract)

LE, N. T., The, D. T., NGO, H. D. (1995): The larvae of trematodes and cestodes in snails, Lymnaea (Lymnaeidae). J. Biol. 17: 11-18. (in Vietnamese with English abstract) Morosov, F. N. (1952): [Trematodes of superfamily Heterophyoidea Faust, 1929]. In. K.I. Skrjabin (ed). [Trematodes of animals and man. Fundamentals of trematodology]. Moscow: Akademiya Nauk Publishing, 6: 153 - 615 (In Russian)

NeuHaus, V. (1940): Entwicklung und biologie von 
Pleurogenes medians Olss. Zool. Jahrb. (Syst.). Jena. 74: $207-242$

OSCHMARIN, P. G., DozENKO, T. K. (1951): [About epizootology of helminthosises among domestic birds in lowlying land near Khanka Lake] Soobchenia DVF AN SSSR, 3: $8-11$

Prudhoe, S., Bray, S. (1982): Platyhelminth Parasites of Amphibia. London: British Museum of Natural History, Oxford University Press: 217 pp.

RAILliET, A. (1924): Les helmithes des animaux domestiques et de I'homme en Indochine. Bull. Soc. Zool. France, 49: $598-603$

Scholz, T., Ditrich, O., GiBodA, M. (1991): Larval stages of medically important flukes (Trematoda) from Vietnane provice, Laos. P1. Metacercariae. Ann. Parasitol. Hum. Comp., 65: 238 - 243

SEY, O. (2000): CRC Handbook of the zoology of Amphistomes. Boston, USA, CRC Press Inc.: 480 pp.

ShIBUE, H. (1953): The first intermediate host of trematode Pleurogenes japonicus Yamaguti. Jap. J. Med. Sci. and Biol., 6 (2): $213-220$

Skov, J., Kania, P. W., Dalsgaard, A., Jørgensen, T. R., BuCHMANN, K. (2009): Life cycle stages of heterophyid trematodes in Vietnamese freshwater fishes traced by molecular and morphometric methods. Vet. Parasitol., 160: 66 - 75 DOI:.org/10.1016/j.vetpar.2008.10.088.

SKRJABIN, K. I. (1953): [Suborder Notocotylidae Skrjabin et Schulz, 1933]. [Trematoda of animals and man. Fundamentals of trematodology]. Moscow: AN USSR Publishing, 8: 7 - 252 (In Russian)
SkrJabin, K. I., BASchKirova, E. YA. (1956): [Family Echinostomatidae Dietz, 1909]. In: Skrjabin, K. I. (Ed.). [Trematodes of animals and man. Fundamentals of trematodology]. Moscow: Akademiya Nauk Publishing, 12: 51 930 (In Russian)

Tamura, K., Peterson, D., Peterson, N., Stecher, G., NEI, M., KuMAR, S. (2011): MEGA5: Molecular Evolutionary Genetics Analysis using Maximum Likelihood, Evolutionary Distance, and Maximum Parsimony Methods. Molecular Biology and Evolution, 28: 2731 - 2739. DOI: $10.1093 / \mathrm{molbev} / \mathrm{msr} 121$.

THANH, D. N. (1980): Identification of freshwater invertebrates in Northern Vietnam. Science and Technology Publisher: 440 - 490 (in Vietnamese)

TKach, V. V., Littlewood, D. T. J., Olson, P. D., KINSELlA, J. M., SwIDERSKI, Z. (2003): Molecular phylogenetic analysis of the Microphalloidea Ward, 1901 (Trematoda: Digenea). Systematic Parasitology, 56: 1 - 15 TruetT, G. E. (2006): Preparation of genomic DNA from animal tissues. In: KIELECZAWA J. (Ed) The DNA Book: Protocols and Procedures for the Modern Molecular Biology Laboratory, Sudbury: Jones and Bartlett Publisher, MA: $33-46$

World HeAlth ORganization (2004): Report of Joint WHO/FAO Workshopon Food-borne Trematode Infections in Asia. HaNoi, Vietnam, 26-28 November, WHO Rept. Ser. no. RS/2002/GE/40(VTN)

XIUMIN L., QINGQUAN C. (1983): [Life-cycle studies of Sphaeridiotrema monorchis sp. nov. (Psilostomatidae)]. Acta Zool. Sinica, 29 (4): 333 - 339 (In Chinese with English abstract)

ACCEPTED SEPTEMBER 26, 2013 